\title{
Timeline of events ... a brief history of what made news this year
}

\section{JAN 9}

A woman gives birth in London to the first baby to have ever been screened before conception for the cancer-causing BRCA1 mutation.

\section{JAN 12}

The US Food and Drug Administration (FDA) published guidelines allowing pharmaceutical companies to distribute journal articles to doctors describing off-label uses for their drugs.

\section{FEB 2}

Incensed by a speech given by President Nicolas Sarkozy the week before, French university researchers and lecturers went on strike over a draft order that would allow university presidents to decide how academic staff should divide their time between research and teaching.

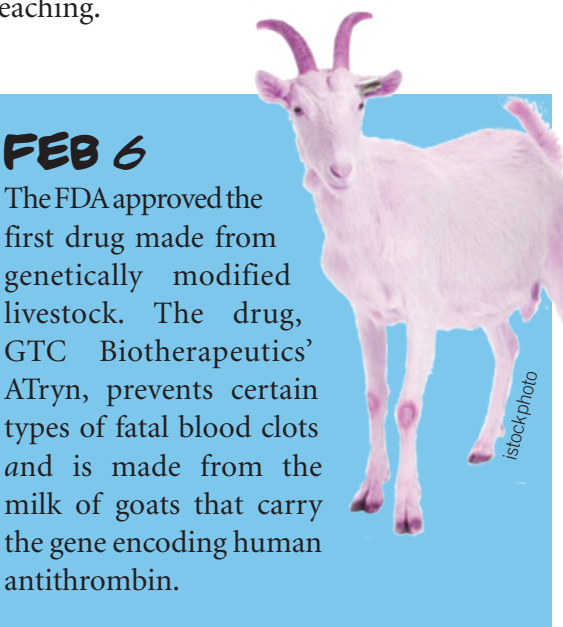

\section{FEB 12}

The US Court of Federal Claims ruled that there was no scientific evidence that the measles-mumps-rubella (MMR) vaccine, or the MMR vaccine in combination with vaccines containing the mercury-based preservative thimerosal, caused autism in three otherwise healthy children.

\section{FEB 13}

The US Congress approved the country's economic stimulus package, allocating $\$ 21.5$ billion for scientific research and development across all US agencies.

\section{FEB 16}

GlaxoSmithKline announced plans to slash prices for patented drugs in less developed countries and to create a 'patent pool' to share research findings on tropical diseases with the goal of more quickly getting drugs to countries in need.

\section{MAR 4}

In the Wyeth $v$. Levine ruling, the Supreme Court found that federal laws do not preempt state laws in personal injury claims. Diana Levine, who won, had argued that Wyeth's drug Phenergan, which is FDA approved, should have described a specific kind of arterial injury risk on its warning label.

\section{MAR //}

Massachusetts state officials banned pharmaceutical and medical device manufacturers from giving gifts to physicians, limited when the companies were allowed to pay for doctors' meals, and required companies to publicly disclose doctor payments over $\$ 50$ for certain kinds of consulting and speaking engagements.

\section{MAR 12}

Pharmaceutical giant Roche acquired the biotech powerhouse Genentech for $\$ 46.8$ billion.

\section{JUN //}

The Empire State Stem Cell Board ruled that New York stem cell researchers could use public money to pay women up to $\$ 10,000$ for egg donations.

\section{JUN /I}

The World Health Organization declared the start of the H1N1 influenza pandemic.

\section{JUL 15}

Maria del Carmen Bousada, who lied about her age to undergo in vitro fertilization in Los Angeles in 2006, died at the age of 69. She had two small toddlers.

\section{JUL 25}

A US District Court granted a motion to release 1,500 documents containing information about journal articles that were ghostwritten by a medical communications firm relating to Wyeth's hormone drugs Premarin and Prempro.

\section{JUL 27}

Hungarian police detained four people accused of carrying out illegal and untested stem cell treatments using embryos or aborted fetuses at a private Budapest clinic.

\section{JUL 30}

Pfizer reportedly reached a $\$ 75$ million settlement with the Kano state government in Nigeria for testing its antibiotic Trovan in children during a severe meningitis epidemic in 1996.

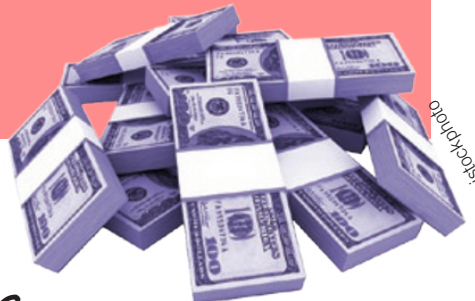

\section{AUG 12}

The FDA released new regulations granting seriously ill people access to experimental drugs if they have exhausted all other commercially available treatments.

\section{OCT 19}

The Obama administration announced a policy shift regarding crackdowns on medical marijuana use. In the 14 states where medical use is legal, federal prosecutors may now focus only on cases involving higher level drug traffickers or people who have used the state laws as a cover story.

\section{OCT 26}

South Korean stem cell scientist Woo Suk Hwang, who admitted in 2006 to forging data, was convicted of embezzlement and bioethical violations. He received a suspended prison sentence, however, and was not convicted of fraud.

Melinda Wenner, New York 